\title{
Homophile Fictions \\ Fan Writing, Science Fiction, and the Birth of Gay Communities in Post-war America
}

\section{Chris West}

Science fiction is a natural, in a way, for any kind of radical thought. Because it is about things that have not happened and do not happen. ... It's very fruitful if you want to present the concerns of any marginal group, because you are doing it in a world where things are different. I was talking to an ex-Mormon, and she said it was science fiction that had gotten her out of the ethos she had been born into, and she said it was not the characters but the landscapes, which of course was the pièce de résistance in the ' $30 \mathrm{~s}$ or in the ' $40 \mathrm{~s}$ - those landscapes made her understand that things could be different. In many social encounters and in many discussions, I've had a terrible time because the one thing my opponents do not have is the sense that things could be different ....

Joanna Russ ${ }^{1}$

It is often asserted - more or less emphatically, with a greater or lesser degree of irritation, and despite or more probably because of the persistence of both popular and elite perceptions to the contrary - that science fiction is a serious business. Frequently science fiction's proponents find themselves explaining that, in spite of the gaudy dust-jackets with their scantily-clad maidens, and in spite of the boy's-own obsession with techno-trickery and techno-babble, science fiction is in fact a type of cultural production that engages serious political questions: overpopulation, the threat of nuclear war, genetic engineering, the moral and ethical dilemmas posed by cloning, the possibilities inherent in alternative socio-economic and socio-cultural arrangements, and so on. As such, the argument goes, science fiction deserves to be taken seriously. Once one is convinced of such a view science fiction can rapidly begin to seem not just an appropriate place for political speculation but also, as Joanna Russ implies above, a natural home - if not the natural home - "for any kind of radical thought." Frequently, too, one encounters in one form or another the related argument that science fiction should have, or does have, a special significance for those who might have reason to wish that the status quo were other than it is. Russ's observation that it is "very fruitful if you want to present the concerns of any marginal group" is exemplary in this respect. Her testimony further indicates that considerations of science fiction that conceive it as a col- 
lection of texts only tell part of the story. Russ tells us that science fiction landscapes helped a woman challenge the codes and protocols of a particular religious institution. This might serve as a reminder that science fiction, sometimes in surprising ways, might help constitute lived experience ... and more than this, because although "science fiction" can denote a particular genre of paraliterary and media texts, it can also designate a subcultural formation or formations. Russ herself, of course, is famous not only for her science fiction and academic work but also for being openly lesbian. ${ }^{2}$ She is thus famous for her contributions to a series of (in her case) overlapping subcultural formations. In recent years there has been a slow but steady growth in academic interest in this interstitial terrain. ${ }^{3}$ In spite of this, the connections between science fiction and homosexuality remain relatively unexplored. ${ }^{4}$ Moreover, those connections that have been remarked have received little sustained or rigorous interrogation.

This article investigates claims made in diverse locations that science fiction fanzines produced in the 1940s and 1950s were among the first gay-community publications in the United States. It combines previously unpublished first-hand testimony from the author of one publication with close textual analysis of another in order to demonstrate that such claims are misleading, at best. At the same time, however, it argues that the intersections between science fictional and lesbian and gay subcultural formations constitute a neglected and potentially profitable area of study for both science fiction scholars and historians of homosexuality. In this way the article situates itself both as a corrective to current historical accounts, and as a contribution towards the as yet unwritten history of homosexuality and science fiction.

Although writing that history is beyond the scope of this article, a few introductory comments that indicate the kinds of materials it would engage and illustrate the kinds of difficulties its authors would face would seem to be in order. The picture anyone attempting such a task would fairly quickly uncover would not be one of - straightforward - silence on the topic. Rather, available perspectives are currently characterised by an extreme unevenness. Hence Andrew Butler's correct assertion, in the first ever edition of Britain's only scholarly sf journal to be devoted to gay and lesbian science fiction (published extraordinarily belatedly in the autumn of 2002), that the connections between sf and homosexuality are a "blindspot" in sf criticism, and his simultaneous adumbration of various instances in which this is not the case. To clarify: the text that Butler dubs "our 'Bible', The Encyclopedia of Science Fiction" $\left(2^{\text {nd }}\right.$ ed., 1993) does not have "entries on homosexuality, gay sf or lesbian sf ... [n]o writer is listed as being openly gay, ... [only two] as lesbians ... [and t] here are no entries for Larry Townsend (whose gay pornographic sf trilogy dates from 1969-70) or Mel Keegan"6 (whose sf novel, Death's Head, was published by The Gay Men's Press in 1991). Neither is there an entry for George Nader, 
whose Chrome (1978), "the first sf novel published by a major house (Putnam) specifically geared for the gay male market,"7 had seen at least three editions prior to the publication of the Encyclopedia. ${ }^{8}$ On the other hand, Butler notes, "The Gay and Lesbian Literary Heritage: A Reader's Companion to the Writers and their Works, From Antiquity to the Present has a sizeable and informed entry on science fiction and fantasy." In addition, James D. Riemer's "Homosexuality in Science Fiction and Fantasy" had been published in 1986, ${ }^{10}$ and Uranian Worlds: A Guide to Alternative Sexuality in Science Fiction, Fantasy, and Horror - the second, more authoritative edition of which contains entries for over 900 texts dealing with relevant subject matter - had seen two editions as well as an abridged third publication in Wayne R. Dynes and Stephen Donaldson's Homosexual Themes in Literary Study by 1992.11 Similarly, in the 1999 edition of Science Fiction Studies that devoted itself to Queer Theory - again a first of sorts - Wendy Pearson argues that lesbians and gay men "remain aliens" in the world of sf (if a little less alien than we were a few years previously), ${ }^{12}$ but this state of affairs pertains even after over ten years of organized gay fan groupings within science fiction subcultures (most notable of which are the Gaylaxians, based principally in North America ${ }^{13}$ ), considerable academic engagement with the phenomenon of slash fiction, ${ }^{14}$ and indeed after the substantial bibliographic work represented by the publication(s) of Uranian Worlds. Surveying critical literature on the topic - or on cognate topics, for investigation of sexuality and science fiction inevitably involves investigation of the much greater volume of writing on gender and science fiction - this pattern is repeated time and again.

The unevenness described above is articulated from, and articulates, a science fictional subcultural perspective. However a similar unevenness can be observed in les/bi/gay apprehensions of science fiction. In her ethnographic study, Science Fiction Culture (2000), Camille Bacon-Smith notes that many lesbian and gay science fiction fans have encountered greater difficulty in coming out as science fiction fans to other lesbian and gay people than they have when coming out as lesbian or gay to members of science fictional constituencies. ${ }^{15}$ This is a reflection of the fact that interest in this kind of cultural production is regarded by a significant proportion of (what I will call as a convenient shorthand) queer people in much the same way as it is regarded by many in the rest of the population, i.e. as pointless, or (you may take your pick) a symptom of immaturity, lack of taste, low level of education, and/or more or less certain evidence of nerdishness or geekhood to boot. On the other hand, however, in an article in the British gay tabloid Boyz on the top ten "women we most wanted to be when we grew up"16 a full half are sf icons: Jamie Somers, a.k.a. the Bionic Woman; Princess Leia (Star Wars); Maya (Space 1999); Servalan (Blake's Seven), and Wonder Woman. Again, Cassell's Queer 
Companion (1995) - ostensibly a handy compendium of and guide to all things lesbian and gay - says under the entry for science fiction that "The genre has caught on among lesbian and feminist writers ... Meanwhile, gay men have litthe more than the possible crush the computer HAL has for Dave in 2001: A Space Odyssey. Thanks." ${ }^{\prime 17}$ But one internet site asserts, to quite contrary effect, that not only lesbians but also "gays, ... bisexuals, and transgender individuals love science fiction" as its subtitle exclaims, in mock exasperation: "Oh, no! Another Gay Science Fiction Page!?!"18.

This unevenness is not, I would submit, a matter simply for science fiction scholars or enthusiasts. It is also, at least potentially, a matter for those interested in the history of homosexuality. A number of questions suggest themselves. If science fiction can be regarded as engaging in serious political speculation, what are the ways in which, historically, it has engaged questions of sexual dissidence? How have sexual dissidents themselves used it or been inspired by it or otherwise motivated by it? When might such queer uses of science fiction have started? Is there a distinctive relationship between modern gay identities and science fictional speculations? Has science fiction, in fact, contributed to the development of lesbian and gay subcultural formations? If so, how?

Although these last two questions may seem rather preposterous they are in fact prompted by a rather titillating sequence of sentences that I quote from the second edition of Uranian Worlds:

A number of lesbians and gay men who became pioneers of the early 1950 s homophile movement originally met through science fiction fandom, a growing network of avid genre readers. Several of their amateur publications, called fanzines - such as Lisa Ben's Vice Versa and Jim Kepner's Toward Tomorrow - were among the first gay-community publications in this country [the US]. The format and the private distribution network of these fanzines made them ideal vehicles for communication and contacts among gay people. ${ }^{19}$

The importance of this for the history of homosexuality and science fiction should be immediately obvious, for what seems to be promised is a history in which homosexuality and science fiction enjoy a far greater affinity than is generally recognized. There is an assertion that science fiction subcultures facilitated encounters between individuals who would later go on to make significant contributions to emergent homophile movements. Moreover, there is the suggestion that through a possibly clandestine yet distinctively queer appropriation of science fictional distribution networks, certain science fiction 
fanzines in fact helped constitute, in their very publication, in their readerships, and in their circulation, embryonic gay subcultures in post-World War II America. It would appear, from what Garber and Paleo write, that in significant ways in this period the science fictional and the lesbian and gay worlds were coterminous. Similar although not identical assertions are made in the first edition of Uranian Worlds - in which Garber and Paleo write that Ben and Kepner's sf fanzines "were among the first few publications in this country that were generated from within the gay community" 20 - and in the introduction to Worlds Apart: An Anthology of Lesbian and Gay Science Fiction and Fantasy co-edited by Garber, Paleo, and Camilla Decarnin and published in 1986. Here the authors state: "A private distribution network developed among enthusiastic science fiction readers, known as fans, who published small, non-commercial 'fanzines' for the purpose of communicating with each other. Lisa Ben's Vice Versa and Jim Kepner's Toward Tomorrow, surfacing within this network, were among the earliest publications in the US to come from the lesbian and gay community." 21

Exciting as this is, careful readers might discern a troubling slippage in the foregoing statements. Garber and Paleo's work subtly shifts from an original assertion that Vice Versa and Toward Tomorrow "were generated from within the gay community," to the specification that they "come from the lesbian and gay community," to the eventual designation of them as "gay-community publications." When all three claims are taken together, the precise nature of the relationship between these publications, their authors, and their readerships seems peculiarly elusive. This state of affairs is compounded by the authors' uncritical deployment of "community" in order to describe the lesbian and/or gay social grouping(s) that, ostensibly, bore forth and received these fanzines. As Alan Sinfield has remarked, 'The question of 'community' is often bizarrely posed, as if it should mean a wondrous unity ... Of course, we [that is, sexual dissidents of various persuasions,] manifest the divisions of class, gender, race, age and education that occur in the wider society. It would be absurd to expect otherwise."22 Sinfield argues that "community" connotes a cosiness that is, unfortunately, frequently lacking in lesbian and gay subcultures; hence his preference for this latter term. In my view this is correct. While I recognise that "lesbian and gay community" has significant resonance in popular discourse, and that this is not the place for a full-scale debate on the relative merits of each formulation, the elision of internal differences that "community" may perform presents a difficulty here, when what is under consideration is, precisely, the nature of a particular social body or bodies at a specific historical conjuncture.

In spite of these difficulties, however, assertions like those made by Garber and Paleo have been repeated elsewhere. For instance, in Science Fiction Audiences: Watching Doctor Who and Star Trek (1995), Henry Jenkins, draw- 
ing explicitly on Garber and Paleo's earlier work, states that "science fiction fandom in the 1950s was closely linked to the emergence of homophile organizations, with fanzines, such as Lisa Ben's Vice Versa and Jim Kepner's Toward Tomorrow, among the first gay community publications in the United States."23 This quotation has itself been excerpted, in a slightly more lengthy form, and posted on the web in an article that documents les/bi/gay activists' campaigns to have a gay character included in (at least) one of the Star Trek shows. ${ }^{24}$ This connection between sf and homosexuality thus achieves a firmer foothold in the public realm. This perhaps explains the following claim, made in an unannotated thumbnail history of gay political organization in a letter to the Very Rev. Gerald Barnes, Bishop, and Father Martin Diaz of the Diocese of San Bernardino, California: "The political Gay movement began in Germany in 1867 and was taken to the US after World War I. The depression and World War II interrupted the movement. It resurfaced in the late 1940's as science fiction clubs." 25 Again, the Feminist Science Fiction, Fantasy, and Utopia website, in accordance with those sources already cited, describes Toward Tomorrow as a "queer SF fanzine" published in the 1950s. ${ }^{26}$

Unfortunately, these assertions are, at best, misleading. This is not to suggest that connections between science fiction and homosexual subcultural formations are nonexistent. This is clearly far from being the case (and I shall return to this point towards the end). What follows derives from my investigation of the claims made in Uranian Worlds and aims to unpack them in a way that will eventually prove productive for others.

\section{Lisa Ben}

The first thing to note is that Vice Versa was not a science fiction fanzine, nor was it inspired by Ben's involvement in science fictional subculture. "Lisa Ben" is, of course, a pseudonym (an anagram of "Lesbian"). The "real" author of Vice Versa was Edythe Eyde. ${ }^{27}$ I corresponded with her briefly in 1999. She contradicted the impression given in Uranian Worlds:

You asked if it were true that my interest in science fiction "fandom" influenced me in creating "Vice Versa." No. At one time, before I knew about "gay", I was a member of a science fiction and fantasy society because I enjoyed reading stories about fantasy and especially weird and eerie tales (much more so than plain science fiction). A few members of that group issued what they termed "fan magazines" devoted to such literature, but none of these home-made mimeographed publications really inspired me to create a gay women's magazine. ${ }^{28}$ 
Ben was quite emphatic on this point: "No, there was no kind of cross-fertilization, as you term it, between my interest in science fiction/fantasy and the 'gay world'."29 These statements would seem to have quite clear implications for the assertions made in Uranian Worlds. Uranian Worlds also claims that Ben helped to organise the Pacificon, "the first major West Coast science-fiction convention," 30 in 1946, and that she had several sf stories published under another pseudonym. These are things she also denies: "Uranian Worlds seems to have some mistaken ideas about me. I never helped organize the Pacificon in 1946. I had only one science fiction story published, not several." ${ }^{31}$ She added that this story was published under a pseudonym, but declined to identify either its title or the name she attached to it. ${ }^{32}$

Not everything that Uranian Worlds says or implies about Vice Versa and Lisa Ben is wrong however. Vice Versa was clearly an "amateur publication." Indeed it has been credited with being "the earliest-known US periodical published especially for lesbians." ${ }^{33}$ In spite of the fact that, as intimated, it was not aimed at a science fictional audience and did not consist primarily of science fictional material, a few other things about it seem worth mentioning. Some of those who read it did become, as the citation from Garber and Paleo might be taken as implying, "pioneers of the early 1950s homophile movement" - for instance "Ann Carll Reid" 34 (a.k.a. "Corky") and Joan Corbin (a.k.a. "Eve Elloree"). Both had subscribed to Ben's magazine and were, respectively, Editor in Chief/Board President and Art Editor of $O N E$ Magazine.$^{35}$ In addition, the magazine did carry at least two sf/fantasy stories, "New Year's Revolution" (by Ben) and "Kiki." The latter is listed as being anonymously authored in Uranian Worlds but was in fact written by Forrest J. Ackerman. Ackerman, whose name is instantly familiar to science fiction cognoscenti, was one of the most famous, if not the most famous, of all sf fans. "[K]nown in fan circles as "Mr Science Fiction," he was a "reader of the sf magazines from their inception, ... served as associate editor of The Time Traveller, the first fanzine ... [and] "is credited with introducing the term SCI FI in 1954." ${ }^{36}$ His friendship with Lisa Ben led eventually to his becoming an honorary member of the Daughters of Bilitis, the first lesbian political organization in the United States. ${ }^{37}$ However, while Ackerman's involvement with Vice Versa and his friendship with Ben clearly instance an intersection between the science fictional and homosexual worlds - and one which would surely merit a lengthier treatment in a history of homosexuality and science fiction it does not, in the end, lend weight to the notion that Vice Versa was a lesbian science fictional publication.

Such a status however might be accorded "New Year's Revolution," the science fictional story that Ben wrote and published in Vice Versa. I turn to it 
briefly because it exemplifies well some of the problems involved in recovering gay meanings from history. Ben notes that "There are many references to certain terms and situations which would now go unnoticed, although at the time I wrote the story these references would have resulted in a few chuckles of recognition from the readers." She elaborates:

The name of the fictional town, for instance, "Jamiston", encompassed the word "jam," which in those days was slang for "straight", or "non-gay." The "Rabney's" bar was a garbled spelling of the real owner's name, which was Barney a non-gay man who must have made a pretty good profit from the gay clientele. ... Movie titles in my story were slightly altered from current films of that time, "When Girl Meets Boy" and "John's Other Wife." remember these.

I had fun dreaming up names for the actresses, too Madelon Mason and Verna Van Dyke. The latter is obvious, but the term Mason, I learned from older gay women, was once slang for a butch. In the '20's Masons and Orders were what was later known as butches and femmes. The name Mona Francisco was an allusion to a notorious drag-queen night-club, Mona's, in San Francisco.

The "Bellevue" theatre referred to the term "belle", once in common usage for an effeminate gay man. "Ye Olde Camping Ground" and its proprietor, $\mathrm{Liz}$ Bean, needs no translation, even today. ${ }^{39}$

Such "translations" as these are invaluable aids to historical understanding. Unfortunately I have unearthed no such guide to Toward Tomorrow. In addition, Jim Kepner died in 1997. As a consequence, trying to substantiate or disprove the claim made in Uranian Worlds regarding Kepner's publication has required a kind of paraliterary sleuthing, one which combines historical inquiry with close textual analysis. ${ }^{40}$ This latter has been important because substantiating or disproving Uranian Worlds's assertions regarding Toward Tomorrow has involved engaging a different problematic from the one presented by Vice Versa, for there is no doubt that Toward Tomorrow is a science fiction fanzine. The question this time, however, is whether it is a "gay-community publication"? I think not, although - since I have almost no firsthand testimony that would prove the point either way - I cannot say so with absolute certainty. Still, the situation seems similar to that reported, via Christopher Isherwood's diaries, by the research psychologist Evelyn Hooker: in 1957 she told him how she had heard of "a queer science fiction club," and went to investigate it. This 
however "turned out to be merely a science fiction club containing some queers." 41

\section{Jim Kepner}

Sources are contradictory regarding Kepner's movements between 1939 and 1943, but it seems clear that he lived in Galveston, Texas (his home town), San Francisco, and Los Angeles at various points between these dates. It is also clear that 1942/1943 marks the point at which he began coming out, that around this time he was reading science fiction avidly, and that he was also busy collecting all the literature he could find which dealt with homosexuality. His library collection "would eventually grow to become the International Gay and Lesbian Archives with tens of thousands of volumes, the largest library of its kind in the world." $" 42$ By 1944 he was settled, at least temporarily, in Los Angeles, and it was here that Toward Tomorrow was published, between the spring of that year and some point in 1945 (after or during March). ${ }^{43}$

In an interview with the film-maker Rosa von Praunheim published in 1980, in which Kepner seems to recall the period 1943-1944, he details how he "came to Los Angeles, got into a science-fiction group and later into the radical movement and essentially went back into the closet. But I talked individually to a lot of the people in the science-fiction group, telling them I was gay, asking them not to tell others, but let me tell people myself, after I get to know them, and I found out that people liked me in spite of that." ${ }^{\circ 4} \mathrm{He}$ adds, poignantly: "I still have some friends in the science-fiction group and now I regard it as insulting, that [notion that], well, Jimmy's a nice guy even if he is queer." However, in a later, self-penned account, a prior history is revealed:

Moving to San Francisco in 1942, I ... [became a]ctive in the local sci-fi club, reading and conjecturing about worlds in which customs might differ from ours[;] I took nine months to find the Gay life for which the city was famous, and my coming out scandalized some otherwise tolerant sci-fi fans, though I remained closeted with most of them. ${ }^{45}$

In a footnote appended to this paragraph he recalls being "Gay-baited" 46 by a member of the Golden Gate Fantasy Society (the main sf fan grouping in San Francisco at the time [hereafter GGFS]), although this, he says, was after he had moved from San Francisco to Los Angeles. Harry Warner, Jr., author of one of the standard histories of sf fandom, records that Kepner considered the GGFS "more cynical and less mature" 47 than the Los Angeles Science Fantasy Society (the society Kepner was most involved with during the publication of Toward Tomorrow [hereafter LASFS]), perhaps because of the gay-baiting he 
experienced from a member of the former group. But homosexuals do not seem to have enjoyed universal approbation in Los Angeles, far from it. In 1944 Jules Lazar and a group of other fans resigned from the LASFS, while Kepner was a member, and in a letter published in Julius Unger's Fantasy Fiction Field, "outed" two members of the club. ${ }^{48}$ Lazar was associated with another LA sf group, called The Outsiders, who had split from the LASFS in 1943. Later (Wamer does not specify exactly when, but the argument about homosexuals seems to have rumbled on through until 1947, at least) one of their number, Francis T. Laney, launched an attack on the LASFS couched in similarly antihomosexual terms. According to Warner, "Survivors of the era still contradict one another about how many fairies were members [of the LASFS] and how ardently they pursued their sex lives in public. Laney at one extreme claimed that only half of the club's members were socially acceptable [i.e. not queer]; others have asserted that only two members were homosexual and that only one of them made that fact plain." 49 In November 1947 Charles E. Burbee resigned as editor of the LASFS's fanzine "because the club wanted to censor material about the homosexuality charges, causing further deterioration in the situation." ${ }^{50}$ Warner does not record whether it was this furor that led to the vice squad putting the LASFS under surveillance (!), but his juxtapositioning of these facts might be taken as suggesting that this was indeed the case. It seems that others may have been interested in whether LA fandom housed a gay community at this time. It also seems that those others may have reached conclusions similar to mine: the vice squad decided that the LASFS were doing nothing subversive or amoral. Rather, "'they were just a bunch of harmless crackpots."

Given Kepner's assertion that his homosexuality "scandalized" some sf fans, and given that later he would regard the kind of acceptance he received from others as "insulting," it seems more than likely that these groups were not predominantly queer, despite the allegations that were bandied about by the likes of Francis Laney. Lisa Ben confirms such a view: "As far as I know, the members of the Los Angeles Science Fiction \& Fantasy Society were non-gay. I did not recognise any of their names in the homophile movement that cropped up later. The only exception was Jim Kepner, who was a member of the abovenamed group ... I doubt if [Toward Tomorrow] was a 'gay' magazine as readership would have been very limited in that group. In those times, one would be inclined to conceal such feelings rather than to publish something which would arouse suspicion. How times have changed!"52 Ben also says that she does not remember Toward Tomorrow, which itself might be taken as suggesting that the zine was not a "gay-community publication," despite the assertions in Uranian Worlds.

Such a conclusion would, moreover, seem to fit with the kind of address evidenced in Toward Tomorrow. The fanzine clearly situates itself primarily 
with respect to the growing science fiction subculture. The editorial of the second issue (June 1944) states that "TOWARD TOMORROW will be a Fantasy Amateur Press Association publication ... [with] some outside distribution." 53 The Fantasy Amateur Press Association (FAPA) was formed in 1937 by the science fiction fan, editor, and writer, Donald A. Wollheim, its purpose being "to facilitate distribution ... of fanzines published by and for members." 54 According to The Encyclopedia of Science Fiction, FAPA was an outgrowth of the National Amateur Press Association, which has a history dating back to 1869.55

Toward Tomorrow's being a FAPA publication is an important thing to consider. FAPA provided a central mailing point for its members: they sent in their publications, bundles of which were assembled and then distributed to all in the association. This, of course, cut postal costs. It also facilitated group discussion. From the second "FAPA mailing" (October 1937) onwards, fans started to devote sections of their zines to comments on the various publications they had previously received. The final mailing of 1943 contained forty one items; by June 1944 this had increased to sixty five. ${ }^{56}$ Thus significant portions of zines came to consist of comments on others' work. Toward Tomorrow \# 4, for example, contains 13 ? pages of comments on the FAPA mailing out of a total of 44 pages, i.e. more than a quarter of its contents. Sf fan and critic Bernadette Bosky notes that "the development of mailing comments gave dialogue priority over monologue [in the zines]. ${ }^{.57}$ Although it is true that publications issued under the auspices of FAPA did not confine themselves to discussions of fantasy, science, or science fiction, the point is that the "dialogue" she refers to here was, institutionally, science fictional. If Toward Tomorrow was indeed a "gay-community publication" it seems that this community consisted of only a few, very isolated gay people. Indeed it seems that it was hardly a community at all, but rather a community-within-a-community, a sub-subculture, assailed both from mundane quarters, and from sfnal areas closer to home. ${ }^{58}$ Science fiction author Frederik Pohl's memoir, The Way the Future Was (1978), would seem to provide testimony which supports such a perspective: Pohl was a member of The Futurians, a New York fan grouping active between 1938 and 1945, and "notable for radical politics." 59 Of his time with The Futurians, Pohl writes:

There was certainly no detectable homosexuality. On the one occasion when a Futurian made some sort of ambiguous approach to another, he was greeted with such revulsion and horror that he cravenly crept back into line; I am not even sure how serious the approach was - I was not present. ${ }^{60}$ 
Pohl does go on to note that "In the breeze from the opened closets of the 70s [this] seems odd, if only on statistical grounds," 61 but, given the foregoing accounts from Kepner and Warner, and the testimony provided by Lisa Ben, Pohl's summary of the prevailing attitude towards homosexuality within sf circles at this time seems broadly applicable. "We were tolerant of diversity, but not that much diversity," 62 he says.

In spite of all this, there are a few hints in Toward Tomorrow that queerity lay close to its editor's heart. Those armed with sufficient extratextual knowledge might have discerned, at various points, a (c)overt gay address. This seems worth pursuing: if Toward Tomorrow might be regarded as participating in and perpetuating a distinctively gay dialogue with at least some of its readers, it might plausibly, if somewhat tenuously, be regarded as a gay-community publication. I will say at once however that the best evidence for this is, to say the least, complicated - since it involves the invocation of what now appears to be an entirely fictitious gay rights organization (as we shall see in due course). Unfortunately, what other evidence exists, so far as I can ascertain, is very slim indeed. For example, in the comments on the FAPA mailing contained in Toward Tomorrow \# 3 (1945[?]), Kepner's response to one zine, Twilight Echoes (which, he believes, is "apparently talking about me") is as follows: “[it] refered [sic] to 'that draft evasion stunt.' I don't get it. Sure I'm 4F, like quite a few fans. And I tried twice, unsuccessfully, to get in the Merchant Marines. I certainly don't recall any sort of draft evasion stunt on my part."63 The possible signal here is " $4 \mathrm{~F}$ ". In Coming Out Under Fire (1990), Allan Bérubé documents one strategy adopted by gay men fearful of antihomosexual policies in the services (which could be severe and were to devastate the lives of tens of thousands of gay men and women ${ }^{64}$ ): "Some of the boys ... sought medical deferments, even though they faced the stigma of being classified 4-F (unacceptable) during the war." ${ }^{\prime 65}$ It is conceivable, then, that Kepner's admission here risks identification of him as a gay man to those "in the know," those who were aware that gays might use their homosexuality as a means of evading the draft. However, this is far from a definitive statement: individuals could be classified 4-F for reasons other than their sexual identity. ${ }^{66}$

Elsewhere in the same issue, in response to comments made by (presumably Jack) Speer in Banshee \# 6, Kepner writes:

You say, "It can't imply that we pretend there aren't two sexes, that perversions are only relative, that women are really men." Why not? In part, geneticists do imply just that. Every person contains in his make-up a certain relative percentage of male and female characteristics. Social custom in our own and in some other civilizations has attempted to force all men into a separate and well-defined role; likewise 
with women. There are differences, but they are relative, so that there are women, in some ways more masculine than the average man, and men far more feminine than most women. It is a demonstrable fact that many women possess a narrow pelvis, that many men have over-developed breasts, that an overwhelming percentage of people possess traits (mental or physical) that are commonly ascribed to the opposite sex. I am not talking about "freaks." Our social system is shot through with the erratic theory of black and whites, i.e., absolute extremes. Science is showing the various shades of greys to be far more numerous than the black and whites, if indeed, any absolute extreme examples exist. ${ }^{67}$

This certainly articulates a liberal (at the least) and progressive opinion, since a popular taking-up of the notion of a continuum of human sexual behaviour (i.e., behaviour characterised by "shades of greys") was not to come until the years after the publication of Alfred C. Kinsey's (et al.) Sexual Behaviour in the Human Male in 1948. Kepner, as I have noted, was writing in 1945. In the second issue of Toward Tomorrow (June 1944), in an article entitled "Concerning Fandom and Ethics," Kepner states that "freedom has an undue proportion of over-sexed, under-sexed and abnormally-sexed individuals." 68 This comment, along with the more extensive reply to Speer just cited, might have given some kind of succour to readers of Toward Tomorrow who were themselves not straight. Taken together they might even have been understood as a defence of gay people's right to be. However, comments such as these can hardly be taken as clear evidence that this fanzine played the role suggested in Uranian Worlds.

Similarly dubious evidence comes from elsewhere in the third issue of Toward Tomorrow. Kepner reviews a series of books which deal with the "race problem," having commented in an article near the start of the magazine: "I heartily suggest that you sample a few of the books reviewed in these pages. You don't have to be immersed in a chivalrous desire to save the Niggers to enjoy them. They are books that parallel other stories of struggles for freedom." ${ }^{\prime 69}$ Could this be an allusion to nascent homophile movements? Possibly so. There is evidence (to which I shall turn later) that as early as 1943 Kepner was willing to join what we would now call a gay rights movement. Could this comment be a hint that sexual dissidents might have a special affinity with various aspects of black life and experience? Again, possibly so. Turning to the books reviewed: there are a couple of remarks which might have acted as subtle pointers for gay or lesbian readers. For instance, Kepner praises Lillian Smith's Strange Fruit (1944), noting that it contains a lesbian character. This is correct, but her lesbianism is the subject of only five pages. ${ }^{70} \mathrm{He}$ also recom- 
mends Claude McKay's Home to Harlem (1928), closing with the line: "And then there's a love angle - a slightly unusual one." This is a suggestive but puzzling comment, because Home to Harlem contains no "love angle", homosexual or otherwise, which I can safely identify as "unusual."

Claude McKay, however, did enjoy many homosexual relationships. According to his biographer, Wayne F. Cooper, though he "rarely discussed homosexuality in his writings ... it inevitably emerged indirectly in his published novels and short stories." $" 11$ One might argue that this is the case in Home to Harlem. The middle section of the novel documents the development of a peculiarly intense friendship between the protagonist, Jake, an itinerant, uneducated Negro labourer, and Raymond, a college-educated, bilingual Haitian. When they first meet Raymond is reading Sapho by Alphonse Daudet, and he comments: "I like the story, but I hate the use of Sapho for its title. ... Because Sappho was a real person. A wonderful woman, a great Greek poet .... Her story gave two lovely words to modern language, ... Sapphic and Lesbian ... beautiful words." 72 Ray's cultural knowledge, his level of education, makes him attractive to Jake, and, possibly, those familiar with the cross-class dynamics of many homosexual relationships might anticipate that a love affair between the two is imminent. Once, when Ray has difficulty sleeping, we encounter this lyrical passage, which might also have fuelled such suspicions:

His father's house was a vast forest full of blooming hibiscus and mimosas and giant evergreen trees. And he was a gay humming-bird, fluttering and darting his long needle beak into the heart of a bell-flower. Suddenly he changed into an owl flying by day .... Howard University was a prison with white warders .... Now he was a young shining chief in a marble palace; slim, naked negresses dancing for his pleasure; courtiers reclining on cushions soft like passionate kisses; gleaming-skinned black boys bearing goblets of wine and obedient eunuchs waiting in the offing ....

And the world was a blue paradise. Everything was in gorgeous blue of heaven. Woods and streams were blue, and men and women and animals, and beautiful to see and love. And he was a blue bird in flight and a blue lizard in love. And life was all blue happiness. Taboos and terrors and penalties were transformed into new pagan delights, orgies of Orient-blue carnival, of rare flowers and red fruits, cherubs and seraphs and fetishes and phalli and all the mosthigh $\operatorname{god} \ldots . .73$

This, arguably, has homoerotic overtones ("gay humming-bird," "obedient 
eunuchs," "orgies of ... fetishes and phalli"). It also evidences heterosexual desire ("slim, naked negresses dancing for his pleasure"). To my mind it reads more like a celebration of sensual plenitude than an encoding of homosexual desire. However, Wayne F. Cooper also says of McKay that he "probably considered bisexuality normal for himself, if not all mankind." 74 Bisexuality, of course, countenances same-sex eroticism. And there is a certain something between Jake and Ray. The former, we are told, pursues the latter "lak a hungry dawg," ${ }^{, 5}$ and when the two are to part there is this exchange:

Jake gripped Ray's shoulder: "Chappie, I wish I was edjucated mahself."

"Christ! What for?" demanded Ray.

"Becaz I likes you." Like a black Pan out of the woods Jake looked into Ray's eyes with frank savage affection and Billy Biasse exclaimed:

"Lawdy in heaben! A li'l' foreign booze gwine turn you all soft?"76

However, sexual desire never hoves into full view. Indeed Billy Biasse is shocked and mocks Jake and Ray because both are marked as heterosexual: they both have female loves. Heterosexuality, of course, has a tendency to colonise and efface other ways of being sexual - both bi- and homo-. Perhaps then, despite the inconclusive evidence, the relationship between Jake and Ray does constitute the unusual love angle to which Kepner alludes.

As far as I can tell, there are only two occasions in all of Toward Tomorrow where homosexuality is referred to explicitly. These are worth noting, in part for the sake of completeness, but more especially because the second, though obscure, provides the strongest piece of evidence that Kepner did intend his zine to contain some kind of gay address, in other words that he himself saw it as having some connection to a gay community.

The first issue of Toward Tomorrow (Spring 1944) contains a novelette by Kepner, rather campily titled "Heavenly, Isn't It?" This details the ascent to heaven of an agnostic, John, who is amazed, in the first place, that heaven exists, and in the second, that the reality of heaven does not match its advance publicity. In this heaven, located on Venus, Saint Peter calls Saint John, "that bastard," and "a dirty rotten liar." In addition, the protagonist's halo will not float as it should but keeps "making sudden and violent contact" with his head, and though there are "many saved souls, floating around on fleecy pink clouds, or flapping through the balmy atmosphere with their befeathered wings," any suggestion of seraphic calm is ruined by (among other things) the many "plunking unskillfully [sic] on [their] harps." 77 The story has a minimal plot: it seems simply to be making the point that hell (which is on Jupiter) is probably 


\section{West}

a far better place to be than heaven. Virgil, John's guide through heaven, tells him that "almost all of the world's scientists, artists, philosophers, etc., have been there ever since they died on earth. Why, instead of Sheol, they've turned the place into a veritible [sic] utopia." 78 John and Virgil are despatched to hell with a minimum of fuss when it is realised that their names are not on the heavenly roster.

The homosexuality in this story comes when John encounters a sharplydrawn "nellie" queen:

"The Lorrd [sic] is the most handsome thing I've ever seen," chirped a rozy-lipped [sic] youth, dressed in a lacefrilled robe, as he swished his hips for emphasis.

"Well, get her," John chuckled.

"Wouldn't mind getting you, honey," replied the blond youth, with an enticing wink. ${ }^{79}$

Although this is a short passage the sexual politics demonstrated here are worth noting: nellie queens who fancy the Godhead get to go to heaven (even if, on arrival, they might decide they would rather be elsewhere). It is interesting too that queens like this are not considered repulsive, neither on account of their sexual desires, nor by virtue of their exaggerated effeminacy. To the narrator indeed these attributes are "enticing."

Nevertheless it is elsewhere in this first issue that a possible gay agenda is most strongly intimated, in a lengthy free verse poem called "Prophesy," attributed to a Conrad Desty. Here are (what turned out to be) the significant lines:

... despise not the small bodies or movements, For in them is the hope of the future, They plant the seeds of thought.

The power of numbers comes later.

Hamidy also shall prosper,

And the ban on comradeship be lifted,

The unspeakable shall be in the open and unashamed. ${ }^{80}$

"Comradeship" and "the unspeakable" might both alert the astute reader that same sex passion is being alluded to here. Walt Whitman speaks of "comrades" in his Calamus poems, and the nature of the love that dares not speak its name is, now, an open secret. However the most significant word is in fact "Hamidy," which I have been unable to locate in any of the (many) dictionaries I have consulted (although Kepner himself believed that it may refer to the "offense [sic] of Ham" [Genesis 9: 20-27] which is "Sometimes interpreted as homosexual 
incest." "81) Work by the historians Martin Duberman and Eric Marcus has proved illuminating here. In Stonewall (1993) Martin Duberman records that the Sons of Hamidy are mentioned by Dorr Legg in his Homosexuals Today 1956: A Handbook of Organizations and Publications (1956) (published under the pseudonym of Marvin Cutler). The name crops up again in an article updating this work by Foster Gunnison, "An Introduction to the Homophile Movement" (1967). Duberman notes, however, that the organization was "possibly apocryphal," and asserts, furthermore, that "Foster accepted [its existence] at face value, as have most historians since." ${ }^{2} \mathrm{He}$ cites Jim Kepner in order to support this claim: Kepner told Duberman that "the Sons of Hamidy was 'a projected organization in 1942-44, starting in Rhinelander, Wisc. ... My Rhinelander pen pal, Wally Jordan, wrote to me \& others that SOH had previous incarnations in the 1880 's \& 1890 's, each time falling victim to 'bitch fights.' He said the organization was led by important people like 'Senators and Generals,' but there is no evidence for these earlier incarnations. ... Years later, he wrote me that $\mathrm{SOH} .$. was simply a wish of his ... It was never an organization. I wrote the original of the account of SOH which appeared in [Dorr] Legg's Homosexuals Today, 1956 - but Dorr, with no personal knowledge of $\mathrm{SOH}$, altered what I wrote to make it seem that $\mathrm{SOH}$ had real existence'." 83 Two principal factors distinguish this from the account of the Sons of Hamidy's "genesis" recorded by Eric Marcus in Making History (1992), which is again derived from an interview with Kepner. First, in Marcus's version it seems that Kepner was led to believe that the reorganization of the Sons of Hamidy was already underway when he heard about them. Second, there is no mention of a clear confession from Kepner's pen pal that the latter had invented the organization. In the present context, however, a further detail present in Marcus's work but absent in Duberman's is most pertinent. I quote the account recorded by Marcus at length:

In 1943, I [Kepner] got into a pen-pal thing accidentally that put me in touch with what I thought was a gay organization. Someone put my name in Weird Tales magazine, and I received several letters from heartsick young girls in the Midwest and from one guy in Rhinelander, Wisconsin, who sent me his picture - very cute. We began the hinting process ....

In one of his early letters, this pen pal asked if I had ever heard of the Sons of Hamidy. After another two or three letters, he described this as a secret national homosexual rights organization started in the 1880 s that fell apart due to bitch fights, which is naturally what gay groups do. He said it was reorganized in 1934 and again fell apart during bitch fights 
178 West

and was now being reorganized with some senators and generals in leading roles. Through three or four letters I asked, "How do I join?" And he kept being vague. By this time he had been drafted and was stationed in Coolidge, Arizona, which he told me was another big centre of the Sons of .Hamidy, along with Rhinelander, Wisconsin. He said, "We have people out looking over San Francisco to see if it's the right sort of town."

I began receiving visits and letters from some of my pen pal's other correspondents and learned that I was national secretary of the Sons of Hamidy! Well, that was a jolt because, poor little me, I was a nobody. With all of these senators and generals, what the hell was I doing as national secretary? And how did I get to be secretary, when my pen pal hadn't even told me how to join yet? It turned out that the Sons of Hamidy was his fantasy, as far as I can tell. ${ }^{84}$

This is a remarkable story: science fiction facilitates a contact which results in a young man having his name and address supplied to those interested in joining an underground gay rights organization which apparently never really existed ${ }^{85}$ Of course, on one level, whether the Sons of Hamidy existed or not does not matter. One might still argue what does matter: first, people thought that it did, and, second, this very plausibly enabled the first issue of Toward Tomorrow to offer a vision of the future in which gays would have some kind of equality with heterosexual people and would not, through self-loathing, or fear of outside aggression, feel the need to conceal their desires. Still, important as this is, it does not really license conceiving of Toward Tomorrow as a gay-community publication. A recent essay on Kepner by Lewis Gannett and William A. Percy III elliptically endorses this view. They write that "The SOH episode raised Kepner's profile as a gay man, with destructive results. Homophobic criticism of him circulated in San Francisco sci-fi circles. Dispirited, Kepner moved to Los Angeles to seek a fresh start ... But Los Angeles proved equally disappointing. The tone of its gay scene ... made Kepner question his place among his sexual peers. Over time he came to realize that he sought a gay community, not one-night stands or even a lover. Adrift and alone, he put his energy into work for the Los Angeles Science Fantasy Society." ${ }^{\circ 6}$ We can add what Gannet and Percy fail to mention: it is at this point, with Kepner involved with the LASFS, that Toward Tomorrow is published. And so, if the Sons of Hamidy never existed, and if Toward Tomorrow itself emerges in the context of Kepner's isolation with respect to any gay sodality, and if it is published, moreover, subsequent to his homophobic hounding out of San Francisco, although the passage cited may well constitute some 
kind of gay address, it has to stand finally as a markedly insubstantial one - or, since it is articulated in the place that it is, perhaps it would be more appropriate to regard it as being, in the end, literally, and forlornly, fantastical.

As noted near the start, the paragraph from the second edition of Uranian Worlds which I have been dissecting is slightly different from that contained in the first edition, of 1983:

A number of lesbians and gay men, who became pioneers of the early 1950s homophile movement, originally met through fandom - a network of avid science-fiction readers. Several of their amateur publications, called fanzines, notably Lisa Ben's Vice Versa and Jim Kepner's Toward Tomorrow, were among the first few publications in this country that were generated from within the gay community. The format and the private distribution network of these fanzines made them ideal vehicles for communication and contacts among gay people. ${ }^{87}$

This phrasing is interesting: saying that a publication is "generated from within the gay community" seems, somehow, a less specific claim than identifying the same as a "gay-community publication," perhaps because the latter formulation carries greater connotations of collective activity. However, even this earlier statement, while perhaps being nearer the mark, might not be totally accurate: Kepner specifies that he was active in fandom before he discovered gay life. In fact he was producing sf fanzines throughout the early forties, at least between 1943 and $1945 .{ }^{88}$ Though he did come out to some fans, as we have seen, there is not sufficient evidence to suggest that he saw the science fictional and the gay worlds as coterminous. It seems most likely, in other words, that Toward Tomorrow was generated more by his involvement with the science fiction community than by his participation in emergent gay subcultures. It is worth noting that in Rough News - Daring Views (1998), a collection of his early journalism, he writes:

Between 1943 and 1951, I moved to Los Angeles, New York, Miami briefly, back to San Francisco, and then to Los Angeles, talking to a few friends ([including] "Lisa Ben" ...) about trying to start a magazine called The Gay Fan. I prepared a few pages and sounded out friends (most were horrified).$^{89}$

Now this sounds as if it might in fact have been a gay science fiction fanzine. But, if this was the case, then it was a zine that was stillborn. 
In correspondence, Lyn Paleo has glossed the claims made in Uranian Worlds thus:

$[\mathrm{I}] \mathrm{t}$ is my understanding that Toward Tomorrow and Vice Versa were specifically science fiction fanzines. Since the authors were gay, the zines were distributed to others they knew to be gay, and ... some of the content was gay-oriented. So, when we said that Toward Tomorrow was among the first gay community publications in this country, we meant that it was a zine coming from the science fiction fan community with specific gay interest specifically distributed to other gay people (but not exclusively).$^{90}$

This, finally, seems most likely. For those interested in the history of homosexuality and science fiction the questions most obviously begged by this formulation are: i) how extensive was this "specific gay interest," and ii) how extensive a circulation among gay people did these fanzines enjoy? In the case of Vice Versa, which did concern itself principally with things lesbian, and was not an sf fanzine, the circulation was, as we have seen, very limited. Nevertheless the fact that parts of publications with such a tenuous existence within the public realm can, in copied form, still circulate some fifty years after their production, and cross the Atlantic to find their way into hands such as mine suggests a more extensive readership than one might at first assume. Toward Tomorrow, on the other hand, probably had more readers than Ben's publication, owing to its being sent out with the FAPA mailing. However, even if some of the FAPA recipients were themselves gay, and even if Kepner distributed it to his non-FAPA gay friends, there is little in it of "specific gay interest," and what there is not immediately apparent.

Perhaps perversely, I do not feel that this damages what I intimated at the beginning of this article: that the connections between homosexuality and science fiction are in fact more varied and complex than the attention they have thus far received would suggest, and that science fiction's particular appeal for sexually dissident readers has not been explored to the extent that it might profitably be explored. For both Kepner and Ben science fiction was important for offering alternatives to oppressively heteronormative regimes of the here-andnow and for opening up the potentiality of the future, and - pace Fredric Jameson's argument that science fiction's "deepest vocation is ... to demonstrate and to dramatize our incapacity to imagine the future, to body forth ... the atrophy in our time of what Marcuse has called the utopian imagination, the imagination of otherness and radical difference"91 - those kinds of sentiments are still espoused by gay people who enjoy sf today. One author of an online article states: "I think that science fiction, like punk, attracted me because of 
my sense of differentness, my longing for an escape from the mundane world in which I had no obvious place ... I'm sure there are latent (or blatant) teen queers out there today discover[ing] other worlds through science fiction." 92 "To me the purpose of fantasy and science fiction is to go where no one has gone before, to open our minds and to expand our intellect. The future is wider, bigger, larger and therefore [it] is a fertile ground for opening up possibilities that are now closed. I think [science fiction i]s the perfect genre to find a place where you can have your freedom because anything can happen here and anything is visible here," says James, a member of the Gaylaxians. Another, Dana, puts it thus: "Science fiction allows us the flexibility to be ourselves." 93 It seems sensible to assume that the affinity for science fiction articulated by gay people in comments like these has enjoyed some historical continuity, and indeed, there is supporting evidence for such a view.

Consider, for example, E.M. Forster's response to Samuel Butler's Erewhon (1872), a text which is sometimes regarded as early science fiction. "The Legacy of Samuel Butler" by Forster was published in The Listener in 1952. He writes:

It is also good to get clear about crime and about disease. [Butler] has left us a legacy here. In Erewhon he reversed their positions, with the happiest results. Crime, in that topsy-turvey land, is an object for sympathy, and it can be cured. Disease is sinful, and is punishable, sometimes by death. The fantasy is profound and fruitful, and, in serious form, it has entered into thoughts of responsible people today. ${ }^{94}$

Forster does not elucidate this last comment but clearly he could well have homosexuality in mind. In Britain in 1952 homosexuality was, in different but overlapping discourses, a crime, a sin, and a sickness. Though the notion that it was a social problem (and not, therefore, primarily a moral or medical matter) was to prove to be in the ascendant, the fifties did witness a growth in medical treatments for homosexuality, for example, aversion therapy. ${ }^{95}$ Erewhonian logic, in which disease equates with moral turpitude and results in capital punishment, and crime necessitates medical intervention, invites a certain ridicule. However it maps precisely the contest between conceiving of homosexuality as a medical condition and conceiving of it as an abhorrent and un-Christian vice. In 1953 Forster, writing in The New Statesman, made a plea for "less social stigma under the existing law" $" 96$ regarding homosexuality. This is an argument for treating a crime with sympathy, in the Erewhonian fashion. These are the ways which, I think, Butler's "profound and fruitful" fantasy figured in Forster's mind, and, possibly, in those of some others. One such may have been 
Alan Turing, the homosexual computer scientist whose work contributed greatly to the cracking of the Enigma codes, and whose test for computer intelligence is still used today. For he, too, was struck by various Erewhonian inversions; for example, the way Butler attached "the taboos on sex to the eating of meat." ${ }^{\prime 97}$ In fact, it is possible that it was Turing's trial for gross indecency, opening on March 31 1952, which prompted Forster to make the pleas he did. It is unclear whether Forster knew Turing personally, but both were friends of P.N. Furbank, a scholar who worked both on Forster and Butler, and who learned from the former of the latter's homosexual predilections. ${ }^{98}$ Turing was "bound over for a year and obliged to take ... organo-therapy for the same period"99 just two months before Forster's Listener article appeared. "Organo-therapy," otherwise known as chemical castration, involved the taking of oestrogen and resulted in the growth of breasts and impotence, which in Turing's case extended beyond the period of his treatment, though this was not meant to happen. It seems likely that the experience, both of the trial and the course of treatment, contributed to Turing's (apparent) suicide in 1954.

The main point though is that Erewhon has, plausibly, been read by queers for queers, and this is the case in at least two senses. Turing's biographer, Andrew Hodges, makes a similar point: "Samuel Butler might well have laughed in his grave at the prophet of the intelligent machine being punished for being sick, and treated for committing a crime." 100 Though he thinks that such irony was not apparent in 1952, I disagree: Forster's elliptical comments both intimate how science fiction may act as a testing ground for speculations about same sex passion, and indicate that sexually dissident individuals in dark, pre-Stonewall days perceived this in much the same way as les/bi/gay sf fans do today. And in this context, information deriving from very disparate sources begins to seem very pertinent. In 1958, for instance, the science fiction author Marion Zimmer Bradley - who among other things contributed to the Mattachine Review - updated Jeannette H. Foster's pioneering study, Sex Variant Women in Literature (1956), and published the additional material in her science fiction fanzine, Astra's Tower. ${ }^{101}$ Gerald Heard, friend of Kepner, Christopher Isherwood and Aldous Huxley, and one of the "leaders" of the "embryonic [American] homophile movement," 102 wrote numerous sfnal novels and stories, including (allegedly) $A E$ : The Open Persuader, which was privately published and distributed by ONE, Inc in $1969 .{ }^{103}$ This is undoubtedly significant: it is an sf novel published by the American homophile movement in the year of the Stonewall riots. Quentin Crisp records that as a child he was inspired by the fantasy writings of $\mathrm{H}$. Rider Haggard, and as an adult went on to compose a science fiction musical which included the immortal line, "Take me; make me your flying sorceress." 104 The musical, unfortunately, was never performed. ${ }^{105}$ The third issue of the British Gay News features a science fiction 
story that is also a thinly-veiled allegory of tensions between radical and conservative tendencies in the then infant British gay liberation movement. Science fiction is deployed in an effort to stem internecine liberationist strife. ${ }^{106}$ All these things and more are parts of that history of homosexuality and science fiction that remains to be written.

In spite of the various negative comments Kepner had to make regarding how the sfnal community received his coming out, in 1959 he was to assert that "Few sci-fi fans are committed to the 'old order of things.' The world is changing, and the faster the better. On morals, as well as social and scientific questions, [sci-fi fans] are open-minded." ${ }^{107}$ Later, he recalled how, at a regular house-party he would attend in the early 1950 s - which was "crowded with a mixture of science-fiction fans, gays, ex-radicals, and other assorted individuals"108 - he often discussed with others the possibility of getting a gay community magazine going, or of founding an activist organization. This never happened. One reason for this, in his view, was that most people thought that the status quo would never change. He disagreed: "unlike most people - due, in part, to my Marxist and science-fiction background - I did not believe that society was static," he says, anticipating precisely Joanna Russ's comments I used at the start of this essay to activate and mobilise the constellation of themes that have informed it - namely, that science fiction is political, that it may have a particular pertinence for sexual dissidents, and that it can inform, in significant ways, lived experience. Although it seems that Toward Tomorrow and Vice Versa did not enjoy the particular status that Uranian Worlds accords them there is, I think, sufficient evidence - and sufficient neglect of the topic to indicate that the history of homosexuality and science fiction would be a history worth writing.

\section{Notes}

I Joanna Russ in Samuel R. Delany and Joanna Russ, "A Dialogue: Samuel Delany and Joanna Russ on Science Fiction," Callaloo: A Journal of African-American Arts and Letters 7, 3 (1984), 29.

${ }^{2}$ It seems appropriate, given the foregoing, that the collective title for a recent series of books edited by Nicola Griffith and Stephen Pagel that are dedicated to lesbian and gay fantasy, science fiction and horror - which in themselves challenge the political institution of compulsory heterosexuality - is, precisely, Bending the Landscape (respectively: 1996, 1998, 2001). 


\section{West}

${ }^{3}$ In addition to work cited or referenced elsewhere in this article, interested readers might consult Wendy Pearson, "After the (Homo)Sexual: A Queer Analysis of AntiSexuality in Sheri S. Tepper's The Gate to Women's Country," Science Fiction Studies 23, 2 (July 1996): 1-22; Pearson, "Homotopia? Or What's Behind a Prefix?," Extrapolation Special Wiscon Issue 44, 1 (Spring 2003): 83-96; Enterprise Zones: Critical Positions on Star Trek, ed. Taylor Harrison et al. (Oxford: Westview, 1996).

${ }^{4}$ See, especially, Wendy Pearson, "Alien Cryptographies: The View from Queer," Science Fiction Studies 77, 26 (1) (March 1999): 1-22 and Chris West, "Perverting Science Fiction: Thinking the Alien Within the Genre," Foundation: The International Review of Science Fiction (forthcoming).

${ }^{5}$ Andrew M. Butler, "Introduction," Foundation: The International Review of Science Fiction. Special Issue: Gay and Lesbian Science Fiction 31, 86 (Autumn 2002), 3. In using "sf" I am following the standard abbreviation for "science fiction" in science fiction scholarship. Hereafter I also deploy the standard adjectival form, "sfnal" for "science fictional".

${ }^{6}$ Butler, "Introduction," 3.

${ }^{7}$ Stephen Donaldson, "Science Fiction," in Encyclopedia of Homosexuality, ed. Wayne R. Dynes, 2 vols. (London: St James, 1990), vol. 2: 1165.

${ }^{8}$ In addition to the original publication I am aware of Chrome (New York: Jove, 1979) and Chrome (Boston, MA: Alyson, 1987).

${ }^{9}$ Butler, "Introduction," 3.

${ }^{10}$ James D. Riemer, "Homosexuality in Science Fiction and Fantasy," in Erotic Universe: Sexuality and Fantastic Literature, ed. Donald Palumbo (Westport, Connecticut: Greenwood, 1986), 145-161.

${ }^{11}$ Uranian Worlds: A Reader's Guide to Alternative Sexuality in Science Fiction and Fantasy, ed. Eric Garber and Lyn Paleo (Boston, MA: GK Hall, 1983); Uranian Worlds: A Guide to Alternative Sexuality in Science Fiction, Fantasy, and Horror, ed. Eric Garber and Lyn Paleo (Boston, MA: GK Hall, 1990); Eric Garber, "Uranian Worlds: The Best of Gay Sci-Fi and Fantasy," in Homosexual Themes in Literary Studies, ed. Wayne R. Dynes and Stephen Donaldson (New York: Garland, 1992), 145-151.

12 Wendy Pearson, "Identifying the Alien: Science Fiction Meets Its Other," Science Fiction Studies 77, 26(1) (March 1999), 53.

13 See Anon., Gay Science Fiction Clubs - GSFS, http://www.gaylacticnetwork.org/clubs/boston.html (accessed 12 January 2004).

${ }^{14}$ See Matt Hills, Fan Cultures (London: Routledge, 2002), 101-103 and 191, n. 9 (for a bibliography of such engagement).

15 Camille Bacon-Smith, Science Fiction Culture (Philadelphia: University of Pennsylvania, 2000), 151.

${ }^{16}$ Boyz (London: Chronos, 3 July 1999), 25. The Boyz offices, in a rather neat twist of fate, were subsequently located on top of one of the London branches of the specialist sf bookshop, Forbidden Planet.

${ }^{17}$ Cassell's Queer Companion: A Dictionary of Lesbian and Gay Life and Culture, ed. William Stewart (London: Cassell, 1995), 225.

${ }^{18}$ Harry, Harry's Sci Fi Page!, http://lambda.lambda.net/ harry/st/scifi.html (accessed 9 August 1999). 
${ }^{19}$ Garber and Paleo, Uranian Worlds (1990), x.

${ }^{20}$ Garber and Paleo, Uranian Worlds (1983), ix.

${ }^{21}$ Worlds Apart, An Anthology of Lesbian and Gay Science Fiction and Fantasy, ed. Eric Garber, Lyn Paleo, and Camilla Decarnin (Boston, MA: Alyson, 1986), 8.

${ }^{22}$ Alan Sinfield, Gay and After (London: Serpent's Tail, 1998), 199.

${ }^{23}$ John Tulloch and Henry Jenkins, Science Fiction Audiences: Watching Doctor Who and Star Trek (London: Routledge, 1995), 243.

24 Anon., History of Unresponsiveness, http://www.webpan.com/dsinclair/vvp/history.html (accessed 17 July 2003; posted 03 July 1995).

25 Father Paul Breton, ST. AELRED'S CHAPEL page six, http://www. geocities.com/staelreds/page6.html (accessed 12 January 2004; text dated April 2001).

${ }^{26}$ Laura Quilter, Feminist Science Fiction, Fantasy, and Utopia: Journals, Newsletters, and 'Zines, http://www.feministsf.org/femsf/crit/zines.html (accessed 17 July 2003).

${ }^{27}$ As Florine Fleischman and Susan Bullough note in their biography of Ben, her real name has been publicized on the internet. I follow their example in deeming it permissible to mention it here. See Florine Fleischman with Susan Bullough, "Lisa Ben (1921)," in Before Stonewall: Activists for Gay and Lesbian Rights in Historical Context, ed. Vern L. Bullough (New York: Harrington Park, 2002), 63.

${ }^{28}$ Lisa Ben, personal communication, 28 June 1999.

${ }^{29}$ Lisa Ben, personal communication, 26 December 1999.

${ }^{30}$ Garber and Paleo, Uranian Worlds (1990), 15.

${ }^{31}$ Lisa Ben, personal communication, 26 December 1999.

32 Ibid.

${ }^{33}$ Jonathan Ned Katz, Gay/Lesbian Almanac: A New Documentary (New York: Harpers and Row, 1983), 618.

${ }^{34}$ NB. Ann Carll Reid is a pseudonym.

35 See Jim Kepner, The Women of ONE, http:/www.usc.edu/isd/archives/oneigla/ Women_of_ONE.html (accessed: 9 August 1999). ONE Magazine was a homophile publication which, while not formally being a part of the Mattachine Society, was closely connected to it.

${ }^{36}$ The Encyclopedia of Science Fiction, ed. John Clute and Peter Nicholls (London: Orbit, 1993), 3-4.

${ }^{37}$ On Forrest J Ackerman's involvement with Ben see Bacon-Smith, Science Fiction Culture, 136-137, and Forrest J Ackerman, Forrey's Brain Honorary Lesbian, http://4forrey.best.vwh.net/lesbian.htm (accessed 21 July 2003).

${ }^{38}$ Ben substituted "When Girl Meets Girl" and "Joan's Other Wife".

${ }^{39}$ Lisa Ben, personal communication, 28 June 1999.

40 Information about science fiction fanzines can be found in The Memory Hole Permacollection Catalog and in The Fanac Fan History Project. References: Greg Pickersgill, Science Fiction Fanzine Bibliography: Memory Hole Permacollection Catalog, Version 6, April 2003, http://www.gostak.demon.co.uk/polarbear.htm (accessed: 23 July 2003). The Fanac Fan History Project, http://fanac.org/ (accessed: 17 December 1999). Toward Tomorrow ran for four issues according to these internet listings; it was supplied to me by Greg Pickersgill (who may be contacted at 
Gregory@gostak.demon.co.uk [no copyright issues attach to fanzines held by $\mathrm{Mr}$ Pickergill but he asks that his contact details be included if materials supplied by him are used in any article]); and, I should note, the copy of the first issue I received has the last six pages missing. Copies may also be available from the ONE Institute in Los Angeles.

${ }^{41}$ Christopher Isherwood, Diaries, vol. 1, 1939-1960, ed. Katherine Bucknell (London: Methuen, 1996), 730. An interesting coincidence is that Kepner and the rest of those involved in ONE "were especially close" to Hooker (Kepner, The Women of ONE, 2; for ref. see above, $n$. 35). It would be nice if Hooker's sf investigations had facilitated her contact with Mattachine; but such a link is unproven.

${ }^{42}$ Anon, Kepner Obituary, http://www.usc.edu/isd/archives/oneigla/KepObit.html (accessed 16 August 1999).

${ }^{43}$ These dates contradict those given in Kepner's obituary (for ref., see above, $n$. 42) but are taken from the publications themselves, so seem fairly sound. Toward Tomorrow \# 4 has no date of publication, but contains a quotation from Amazing Stories of March 1945, hence my dating of this issue. (The Memory Hole dates this issue as June 1945.) ${ }^{44}$ Rosa von Praunheim, Army of Lovers (London: Gay Men's Press, 1980 [1979]), 43.

45 Jim Kepner, Rough News - Daring Views: 1950s' Pioneer Gay Press Journalism (New York: Harrington Park, 1998), 2.

${ }^{46}$ Ibid., 399. According to Harry Warner, The Golden Gate Fantasy Society changed its name to the Golden Gate Futurian Society "a few years" after 1939 (Harry Warner, Jr., All Our Yesterdays: An Informal History of Science Fiction Fandom in the Forties [Chicago: Advent, 1969], 247). Some sources record that Kepner was a member of the GG Futurian Society, but the name given in the main text here is the one that Kepner uses when recalling the incident referred to. I would like to thank Andrew Butler and subscribers to the International Association for the Fantastic in the Arts mailing list, the Science Fiction Foundation committee, and the British Science Fiction Association committee bounce for their help in clarifying this point.

${ }^{47}$ Warner, All Our Yesterdays, 247.

${ }^{48}$ It seems likely that one of those outed was Kepner himself, but I have only circumstantial evidence to prove the point.

${ }^{49}$ Warner, All Our Yesterdays, 252.

${ }^{50} \mathrm{Ibid}$.

${ }^{51}$ Ibid., 253.

${ }^{52}$ Lisa Ben, personal communication, 26 December 1999.

$53 \mathrm{Jim}$ Kepner, Toward Tomorrow [TT]\# 2, June 1944, p. 2.

${ }^{54}$ Clute and Nicholls, The Encyclopedia of Science Fiction, 415.

55 Ibid., 46.

${ }^{56}$ Warner, All Our Yesterdays, 197.

57 Bernadette Bosky, "Amateur Press Associations: Intellectual Society and Social Intellectualism," in Science Fiction Fandom, ed. Joe Sanders (Westport, CT: Greenwood, 1994), 181-193, at 183.

${ }^{58}$ I use "mundane" in its fannish sense, as referring to the non-science fictional world.

${ }^{59}$ Clute and Nicholls, The Encyclopedia of Science Fiction, 457.

${ }^{60}$ Frederik Pohl, The Way the Future Was: A Memoir (London: Victor Gollancz, 1978), 
60.

${ }^{61}$ Ibid.

62 Ibid.

${ }^{63}$ Kepner, TT \# 3, 1945?, p. 23. TT \# 3 is undated. It contains reviews of a number of books published in 1944 and contains comments on the Fall FAPA mailing, so seems likely to have been published early in 1945. The Memory Hole dates it as being published in January of that year.

${ }^{64}$ Homosexuality, or homosexual actions, were sufficient grounds for discharge including dishonourable discharge - from the US services throughout World War II. However Army and Navy policy changed markedly over the duration of the war, as well as being unevenly implemented from place to place. See Allan Bérubé, "Marching to a Different Drummer: Lesbian and Gay GIs in World War II" (1981), in Hidden From History: Reclaiming the Gay and Lesbian Past, ed. Martin Duberman, Martha Vicinus, and George Chauncey, Jr. (New York: Meridian, 1989 [1990]), 383-394, and Allan Bérubé, Coming Out Under Fire: The History of Gay Men and Women in World War Two (New York: The Free Press, 1990).

${ }^{65}$ Bérubé, Coming Out Under Fire, 4.

${ }^{66}$ Writing in 1966, David Sanford notes that drug addicts, alcoholics, and homosexuals all qualified for medical deferments from the US Armed Forces under directions issued by the Defense Department. See Sanford, "Boxed In," The New Republic: A Journal of Opinion 134, 21, issue 2687, 21 May 1966, pp. 8-9.

${ }^{67}$ Kepner, $T T$ \# 3, p. 25.

${ }^{68}$ Kepner, $T T \#$ 2, p. 7.

${ }^{69}$ Kepner, $T T$ \# 3, p. 12.

${ }^{70}$ Lillian Smith, Strange Fruit (New York: Reynal and Hitchcock, 1944), 162-166.

${ }^{71}$ Wayne F. Cooper, Claude McKay, Rebel Sojourner in the Harlem Renaissance: A Biography (Baton Rouge: Louisiana State University Press, 1996 [1987]), 75.

72 Claude McKay, Home to Harlem (New Jersey: The Chatham Bookseller, 1973 [1928]), 128-129. I preserve the idiosyncratic spelling contained in the text.

${ }^{73}$ Ibid., 157-158.

${ }^{74}$ Cooper, quoted in Marjorie Garber, Vice Versa: Bisexuality and the Eroticism of Everyday Life (New York: Simon and Schuster, 1995), 123.

${ }^{75}$ McKay, Home to Harlem, 273.

76. Ibid., 272.

${ }^{77}$ Kepner, $T T$ \# 1, Spring, 1944, pp. 14-15.

${ }^{78}$ Ibid., 22.

${ }^{79}$ Ibid., 16.

${ }^{80}$ Ibid., 24.

${ }^{81}$ Kepner, Rough News - Daring Views, 364, 407.

${ }^{82}$ Martin Duberman, Stonewall (New York: Plume, 1993 [1994]), 155.

${ }^{83}$ Ibid., 293-294, n. 13.

${ }^{84}$ Eric Marcus, Making History: The Struggle for Gay and Lesbian Equal Rights 1945 - 1990: An Oral History (New York: HarperCollins, 1992), 46.

${ }^{85}$ Perhaps this experience lay in Kepner's mind in 1959 when he argued in a debate with 
Dorr Legg, conducted in ONE Magazine, whether to launch "a homosexual pen pal club" (Kepner, Rough News - Daring Views, 350). Kepner was for this, Legg opposed to it. And in the course of his defence of the notion, Kepner says that he had known "several persons" (347) who used sf magazine letter columns to meet friends and prospective partners - as he puts it, "brothers under the skin."”

${ }^{86}$ Lewis Gannet and William A. Percy III, "Jim Kepner (1923-1997)," in Before Stonewall, 124-134, at 127.

${ }^{87}$ Garber and Paleo, Uranian Worlds (1983), ix, my emphasis.

88 The Fanac Fan History Project attributes two other fanzines to Kepner: Toward Yesterday (two issues, both dating from 1943), and Fen (again, two issues: December 1943, and December 1944), http://fanac.org/Fannish_Reference_Works/Bibliographies/ Fanzine-t.html (accessed 17 December 1999). The Memory Hole differs slightly, listing only one issue of Toward Yesterday (December 1943). In an editorial in Toward Tomorrow \# 4, however, Kepner writes "I first conceived the idea of publishing for the fan field three years ago while enroute [sic] from Galveston, Texas." This, then, would probably have been in 1942. He continues: "I have since published over a dozen, of various sorts and sizes, and have had a hand in as many more" (11). I have been unable to locate all of these.

${ }^{89}$ Kepner, Rough News - Daring Views, 2.

${ }^{90}$ Email from Lyn Paleo, 30 June 1999.

${ }^{91}$ Fredric Jameson, "Progress Versus Utopia; or, Can We Imagine the Future?," ScienceFiction Studies 27, 9 (July 1982), 153.

${ }^{2}$ Larry-bob, Larry-bob's Generic Queer Homepage: Gay Science Fiction, (Dated 3 November 1997), http://www.io.com/ larrybob/gayscifi.html (accessed 9 August 1999).

93 Tulloch and Jenkins, Science Fiction Audiences, 242-243.

${ }^{94}$ E. M. Forster, "The Legacy of Samuel Butler," The Listener, 12 June 1952, p. 955.

${ }^{95}$ On homosexuality as a social problem see Alan Sinfield, Out on Stage: Lesbian and Gay Theatre in the Twentieth Century (London: Yale University Press, 1999), 237-239; on medical treatments for homosexuality see, e.g., Jonathan Dollimore, "The Challenge of Sexuality," in Society and Literature 1945 - 1970, ed. Alan Sinfield (London: Methuen, 1983), 51-85, esp. 62.

${ }^{96}$ E. M. Forster, "Society and the Homosexual: A Magistrate's Figures," The New Statesman and Nation, 31 October 1953, pp. 508-509, at 509.

${ }^{97}$ Andrew Hodges, Alan Turing: The Enigma of Intelligence (London: Unwin, 1985 [1983]), 73.

${ }^{98}$ See P. N. Furbank, E. M. Forster: A Life, 2 vols. (London: Secker and Warberg, 1978), vol. $2: 4$, n. 1 .

${ }^{99}$ Turing, quoted in Hodges, Alan Turing, 473.

100 Ibid., 473.

101 See Jonathan Ned Katz, Gay American History: Lesbians and Gay Men in the USA. (New York: Avon, 1976), 964, n.147; and Garber and Paleo, Uranian Worlds (1990), 2829.

102 Ian Young, The Stonewall Experiment: A Gay Psychohistory (London: Cassell, 1995), 48. 
103 There has been some confusion over the appropriate attribution for this anonymously authored work, although it seems certain that Heard played some part in its creation. See the review by Kepner in International Gay and Lesbian Review, ed. Walter L. Williams, http://cellar.usc.edu:9673/review/iglr/review.html?rec_id=560 (accessed 20 July 2003).

104 Quentin Crisp, The Naked Civil Servant (London: Flamingo, 1985 [1968]), 199.

${ }^{105}$ See ibid., 15, 41-42, 199-200.

106 Glenys Parry, "2032: A Gay Odyssey," Gay News (London) no. 3, July 1972, pp. 67. (Uranian Worlds attributes this to Neville Gadd; Glenys Parry is the name appended to the text.)

${ }^{107}$ Kepner, Rough News - Daring Views, 347.

${ }^{108}$ Marcus, Making History, 47. 